\title{
Urban Bioregions and Territorial Identities in Romania. The Role of Information and Communication Technology
}

\author{
Adrian-Daniel MUNTEAN¹, Remus-Adrian CARANFIL'1, Oana-Ramona ILOVAN ${ }^{*}$ 2, 3 \\ * Corresponding author \\ 1 Babeş-Bolyai University, Faculty of Geography, Territorial Identities and Development Research Centre, Cluj-Napoca, ROMANIA \\ 2 Babeș-Bolyai University, Faculty of Geography, Department of Regional Geography and Territorial Planning, Territorial Identities \\ and Development Research Centre, Cluj-Napoca, ROMANIA
}

3 Humboldt-Universität zu Berlin, Department of Geography, Berlin, GERMANY

$\triangle$ adriand.muntean@gmail.com (D) https://orcid.org/oooo-0oo3-2160-2206

$\triangle$ remus.adrian10@gmail.com (D) https://orcid.org/oooo-0oo2-9714-0848

$\triangle$ oana.ilovan@ubbcluj.ro (D) https://orcid.org/oooo-ooo3-2075-1808

DOI: 10.24193/JSSPSI.2021.8.07

https://doi.org/10.24193/JSSPSI.2021.8.07

$\mathbf{K} \mathbf{e} \mathbf{y} \mathbf{w} \mathbf{o} \mathbf{d} \mathbf{~ s :}$ territorial resources, bioregionalism, eco-farming, smart initiatives, regeneration, sustainable development, inequality, regional development, COVID-19

\begin{abstract}
A B S T RA C T
This article explores the current measures and initiatives implemented in Romania to determine what is the role of information and communication technology (ICT) in creating bioregions, and especially in how cities, as potential urban bioregions, play a part in this process. The exploratory documentation and database creation was done through keyword-search on the Google search engine, because of the current COVID-19 restrictions. The initiatives found by keyword searching were then divided into two categories, ICT-related, and non-ICT, and represented in table format. The keyword-based search has led to several results, which were displayed using ArcMap 10.5 and analysed by being superimposed on the historical and development regions of Romania. Firstly, results showed that, in Romania, a bigger concentration of population did not necessarily correlate with a higher number of sustainable practices. Secondly, that cities' bio/eco food demand, as well as fertile soil, created the premise for the start of numerous eco/bio-certified farms and businesses. Thirdly, cities, and especially the four major regional capitals (Bucharest, Iași, Cluj-Napoca, and Timişoara) had more practices and especially smart-based ones. Finally, results indicated a large regional inequality in terms of the number of sustainable practices, with eastern regions being shallower, while western regions and those counties in proximity to important urban centres being favoured. This exploratory study helps to understand the stage of reaching the aims of the bioregional paradigm in Romania.
\end{abstract}

\section{INTRODUCTION}

Human society is always changing, and there are many reasons for this. The most important one is, arguably, survival. Others could be prosperity, community, family, and so on. In today's world, many have decided to think about the future differently. Although there are sceptics about the current issues plaguing our planet (ever-intensifying climate change, poverty, accelerated consumerism depleting the planet's resources, social inequity, ferocious globalism changing the balance of politics, food chains, clash of cultures, borders, and so on), more and more are both stated and written about building a sustainable, green, and smart future for mankind.

When local sustainability is constantly challenged by global approaches to development, asking many questions or contesting its successful 
implementation (Petrişor, Susa and Petrişor, 2020), with environmental issues being "a downside of urban development" and being paid limited attention in Romania (Petrişor and Petrişor, 2020, p. 37), approaches differ in policy, practice, and research. However, recently, an evolving trend towards building sustainable urban environments has surfaced. The socalled urban bioregion is a relatively new concept in regional geography lacking much information and scientific literature in Romania (cf. Ilovan and Ciupe, 2021; Ilovan, Ciupe and Marin, 2021; Ilovan et al., 2021), but meaningfully introduced in regional planning during the years, and especially lately (see Atkinsons, 1992; Fanfani and Duží, 2019, Magnaghi, 2014, 2020), also drawing on some approaches derived by the original legacy referring to a specific "urban bioregionalism" strand (Snyder, 1994).

Since more than half of the Earth's population lives in cities, it is tempting to try to build around that, turning cities into oases of sustainability, or following this idea. In reality, it is not so easy to put it into practice. ICT's involvement in the modern society may be another step on the ladder towards sustainability. Some are of the opinion that ICT could have a positive impact on sustainable practices in the future (cf. Avadhanulu, 2011; Bibri, 2019; Drepaul, 2020; GeSI, CSCP, 2012; Kumar, 2020).

Romania is just one of the countries that have started to add these words into their dictionary. However, the historic and socioeconomic context might prove to be a hurdle in Romania's road towards reaching a sustainable development paradigm. It still traverses a transitional period, experiencing globalisation and "accentuation of inequality as well as aggravation of environmental issues" (Guvernul României, 2018, p. 13).

Because in Romania the subject of urban bioregions was only tangentially debated in the scientific literature, there was a need to first discuss the urban area. The term bioregion is discussed in the Theoretical Background section. We aimed to spotlight the urban characteristics that are linked to the subject of urban bioregions, such as the surroundings (of the urban area), the urban inhabitants' occupations, and the components of an urban area (what the urban refers to). We focused on these urban characteristics because an important aspect of the urban bioregions is the relationship between urban and rural areas (or the urban area and its surroundings).

Taking into consideration the aforementioned, we can say that "an urban area is the region surrounding a city. Most inhabitants of urban areas have non-agricultural jobs. Urban areas are very developed, meaning there is a density of human structures such as houses, commercial buildings, roads, bridges and railways" (National Geographic Encyclopedia, 2020). "Urban areas can refer to towns, cities, and suburbs. An urban area includes the city itself, as well as the surrounding areas" (National Geographic Encyclopedia, 2020). In the scientific literature, the city is considered "the complex form of human settlement having variable dimensions and urban endowments, usually with politicaladministrative, industrial, commercial and cultural function" (Gheorghiu, 2009, p. 7).

Although starting our research from this definition of the urban region, we underline that in this study we considered the following as a definition of a certain type of this urban region: the urban bioregion characterised as "the appropriate conceptual reference for a territorial project which is designed to integrate the economic (referred to the local territorial system), political (self-government of inhabited areas and work places), environmental (territorial ecosystem) and living (functional and inhabited areas of a group of cities, towns and villages) components of a socioterritorial system that pursues a coevolutionary balance between human settlement and the environment, reestablishing new forms of the long-term relationships between city and countryside that tend towards territorial fairness" (Fanfani, 2020, pp. 35-36). An example of long-term relationship between city and coutryside is the agriurban commons, defined "as any activity of vegetal and animal production located in or nearby urban areas, on native or artificial soils" (Fanfani, 2020, p. 151).

The aim of this exploratory study is to identify as many Romanian attempts as possible towards building a sustainable urban bioregion, with exclusive attention to those that also have an ICT component. These could be anything from eco-farming to smart projects, to energy consumption and recycling. The assumption that bioregional oriented processes may be partly based on ICT tools adoption was realised in the context of the COVID-19 pandemic and encouraged by this, because of the lockdown and restricted mobility in Romania. We identified no scientific papers delving into this emergent topic, and therefore it was worth researching, in order to fill this gap, even though the current COVID-19 restrictions only allow for online documentation. However, this suited our purpose when collecting data.

The hypotheses from which we started our endeavours are the following: (a) The counties ${ }^{1}$ with more population (and also higher population density) will have more initiatives, and their number is based on the general development level, (b) The counties with more arable land will have more farming-oriented approaches, (c) The initiatives in cities will mainly be

\footnotetext{
${ }^{1}$ A county is a Romanian territorial division. There are 41 counties and the capital city Bucharest (which has its own administration similar to a county). Each county consists of a territory made of cities, towns, and rural communes. At European level, a county is the administrative equivalent of NUTS 3 .
} 
smart oriented, and finally, (d) The initiatives will be more punctiform than larger scale.

The aim was further divided into objectives and research questions. The research questions were as follows: Has the Romanian society started implementing projects that bring it closer to the sustainable development paradigm? If yes, how many (completed) projects, (active) businesses, and (implemented) solutions are there, and which of them predominate? How many of them have an ICT component and which are only "offline"?

The research objectives are the following: (a) to identify completed projects, active businesses, and implemented solutions focused on sustainable development across Romania's territory; (b) to classify those initiatives into non-ICT and ICT-related; (c) to diagnose Romania's territory.

In order to achieve these objectives, we conducted our research exclusively online. The exploratory documentation and database creation was done through keyword-search on the Google search engine, because of the current COVID-19 restrictions. The initiatives found by keyword searching were then divided into two categories, ICT-related, and non-ICT, and represented in table format. The keyword-based search has led to several results, which were displayed using ArcMap 10.5. However, the key stages in collecting and processing the data are presented extensively in the methodology section, under number 3 below.

After a brief review of the scientific literature on the subject of urban bioregions, this article goes on with a presentation of the methodology, and then examines the Romanian approach to bioregional practices and to the urban bioregion, presenting and discussing the results of a focused keyword searching (i.e. eco, smart, bio, sustenabil [sustainable]) and realising an overview of initiatives related to urban bioregional practices.

\section{THEORETICAL BACKGROUND}

In this section, after debating the term bioregion (or bioregionalism), we discussed other terms related to urban bioregions and the relations among those (i.e. why those terms are related to the urban bioregion). First, we discuss the term bioregion. The bioregional philosophy "addresses both social and physical aspects of the human relationship to the environment, and as such is complemented by the literature related to behavioral change and ecological planning" (Church, 2014, p. 2). Furthermore, this "philosophy is, in part, a reaction against globalization and capitalism, which are thought to contribute to the creation of generic, highly consumptive human settlements, with poor regard for environmental consequences" (Church, 2014, p. 2).
Bioregionalism can be understood through a range of concepts. For instance, a strong bond between communities and their land helps create territorial identities, a sense of belonging, and sustainable practices (Banini and Ilovan, 2021a, 2021b; Dodge, 1981, cited in Harris et al., 2016, p. 3; Gray, 2007; Havadi et al., 2017; Ilovan et al., 2016; Thayer, 2003; Tuan, 1974; Woolstencroft, 2003). Harris, attempting to delineate a bioregion in British Columbia, Canada, for food systems planning and design, considered that bioregionalism is a binder of the landscape created by both human and ecological components (Harris et al., 2016, p. 3).

Fanfani and Duží (2019) underline the idea that bioregionalism is a diverse flow of ideas and concepts. More than that, bioregionalism (or, in this case, urban bioregions) represents the way regions (or territories in general) will develop by emphasising sustainable development, considering aspects such as "participative processes, fair resource management, urban-rural reciprocity, governance, community, etc." (Ilovan et al., 2021, p. 269).

This subject was indirectly debated by Filip (2009), using terms strongly related to bioregions (urban bioregions) such as green urbanism, urban village, and ecopolis. Green urbanism does not seem to be a new concept because it is very similar to "the garden city movement" (Filip, 2009, p. 321). This term considers the "eco" part of what an urban bioregion means, its feature being related to "smart growth principles such as the principle of environmental boundaries, the principle of managing the anthropogenic needs, the principle of eco-efficiency, the principle of welfare and the principle of equality" (Filip, 2009, pp. 321-322). Green urbanism "represents a valid alternative for setting up cities that are attractive, in harmony with nature" (Filip, 2009, p. 322).

The urban village is seen as a "response to the dysfunctionalities characterizing the contemporary city" (Filip, 2009, p. 322). This concept is different from other concepts because "the initiators have the vision of the urban village as an urban entity small enough to offer the advantages of an authentic community, but big enough to offer diversity" (Filip, 2009, p. 322).

The last concept, named ecopolis, is the most strongly related term to urban bioregion features out of these three because it aims "to create urban communities that are healthier, more ecological, in harmony with nature, by means of urban, ecologic and community-focused activities" (Filip, 2009, p. 323). Considering the definitions of these three terms, we can strongly argue that they are related to urban bioregions, because they support activities such as "going back to nature, reconsidering the everyday way of life, reorganizing the priorities of the requirements, and establishing harmony between anthropogenic activities and natural flows" (Filip, 2009, p. 323). 
There are other concepts related to urban bioregions such as innovation (Huggins and Thompson, 2018), learning region (Asheim, 2018), sustainable region (Gibbs, 2018), civic engagement (Ayres, 2018), and local leadership (cf. Havadi-Nagy et al., 2017; Ilovan et al., 2016). Other related concepts that are notable but will not be detailed are eco-villages, alternative lifestyles, self-reliance, and self-provisioning (Fanfani and Duží, 2019).

One of the key issues that urban environments present and thus require a bioregionalist approach is that they "have been shown to be unsustainable in the sense that their footprints greatly exceed, or overshoot, their bio capacities by typically 15-150 times" (Doughty and Hammond, 2017, p. 481). Therefore, they need to reduce "environmental footprints by encouraging greater self-reliance and low-impact development across regions, whilst protecting indigenous ecosystems" (Doughty and Hammond, 2017, p. 482).

When discussing how a city can get closer to becoming an urban bioregion, Poli (2015) suggests increasing the number of square meters of green area per person in agglomerations, creating a local food system, recycling used water for farming, as well as implementing cycle-tourism (2015). Communities' response to the environment can be influenced through the efforts of NGOs (Hartel et al., 2014; Ilovan, 2020a, 2020b, 2020c, 2020d, 2020e; Kobulniczky and Ilovan, 2020).

Very few cities across the globe come close to being deemed veritable urban bioregions, because sustainability cannot easily be achieved. Current settlements of this type are small, one being India's Auroville, benefiting from eco-friendly infrastructure, as well as from investment into ICT (Avadhanulu, 2011). The ICT industry is believed to play a large role in facilitating a green lifestyle for the cities of the future (GeSI, CSCP, 2012).

We observe the similarity between economic regionalisation (economic region) and urban bioregions when we analyse economic activities. Not all economic activities occur in one territory, but the production of goods and services depends on the distribution of other materials/components from multiple locations that could be outside of the regions. This is similar to urban bioregions when we focus on the relationship between rural and urban areas and on how important they are for each other. More specifically, in the rural area, there are activities usually not present in the urban area (growing vegetables) and vice versa (using the city as a sales market). Thus, the similarity between this economic regionalisation and urban bioregions is that not all activities are taking place in one area (Jones, 2018, p. 109). Economic regionalisation can be a tool to understand how urban bioregions will impact the surrounding regions. If a region (sub- or supranational) will become more oriented towards the ecological paradigm, promoting innovative and fair production and consumption (Scott Cato, 2013), then that aspect will reflect in the pollution levels as well as in the nature of products that the region buys and sells, and in the behaviour of companies that activate in that region (Jones, 2018).

Another idea enabling our understanding of urban bioregions is the one relating the geography of experience and urban bioregions, considering various types of regionalism. Developing relations between regions is strongly connected to the relations between urban and rural (one important idea of urban bioregions) (Entrikin, 2018, p. 44). Of outstanding relevance for understanding the way the urban area can be used by nearby rural areas (for selling local products) and vice versa (the rural area to grow quality products) is the concept of the city's foodshed (cf. AckermannLeist, 2013; Hedden, 1929; Kloppenburg, Hendrickson and Stevenson, 1996).

According to Entrikin (2018), we may imply that an urban bioregion could be both atavistic and progressive in terms of regionalism. Atavistic because it would operate under the mantra of 'think globally, act locally', binding communities together in a shared effort to make their living space more sustainable and in tune with nature; progressive because innovation and specialists in terms of green industry and societal advancements around the globe regarding sustainability need to circulate the world and be implemented by every single bioregion to make the whole planet sustainable.

One similar aspect between innovation and urban bioregions is underlined by the fact that one of innovation's explanatory factors is the cooperation achieved through ecosystems (Huggins and Thompson, 2018, p. 116), an aspect very often met in urban bioregions.

Another similar aspect between these two is that entrepreneurs are increasingly depicted as agents of economic and social change that develop communities, often enacting a collective identity that facilitates and shapes development (Huggins and Thompson, 2018, p. 116). Introducing innovation means economic and/or social change because, in an urban bioregion, there are changes in the community's behaviour that can improve lifestyle (Huggins and Thompson, 2018, p. 126).

Also, the concept of learning region is related to urban bioregions because one perspective on learning regions presumes that those regions should be looked upon as a strategy for the formulation of longterm partnership-based development, initiating learning-based processes of innovation and change (Asheim, 2018, p. 131). More precisely, in bioregional terms, learning is also conceived as re-learning to (re)in-habit a place based on its peculiar characteristics and strengths (i.e. heritage, place specific knowledge 
creation, and "retro-innovation" processes may contribute to cognitive improvement) (Stuiver, 2006). These are concepts often met when researching urban bioregions, but the most significant one is the long-term partnership, similar to the one between urban and rural regions (which brings the idea of sustainable development) (Asheim, 2018, p. 133). Integrating innovation in the regional economy seems to contribute to the bioregional effort.

Further on, the relationship between sustainable regions and the urban bioregion is represented by ecological protection, which is a key component of the sustainable regions, and the green economy, which is focusing on green, low carbon, or cleantech economy. The above-mentioned are common features of sustainable regions and urban bioregions. More or less, sustainable regions and urban bioregions aim to develop green economies (based on green industries) (Gibbs, 2018, p. 182). Space and place are key factors to understand where on the Earth sustainability has the potential to be implemented (Gibbs, 2018), and therefore, the premise to creating a viable urban bioregion. When considering the ecological footprint of economies, special attention needs to be paid to the "ecological shadow" that the economy produces, that is, just how many of a region's material goods are produced outside of the region in case (Atkinson, 1992, p. 333). Ideally, for urban bioregions, more should be produced within such regions than outside them (Thayer, 2013).

Finally, other two concepts, civic engagement, and local leadership, are related to urban bioregions, regional governance, and democracy (another feature of urban bioregions). Civic engagement is characteristic of urban bioregions because it refers to the improvement of democracy, popular participation, and empowerment of local people through civic initiatives (Ayres, 2018; for Romania, cf. also Havadi-Nagy et al., 2017; Ilovan et al., 2016).

A final remark on the literature about changing the world toward a bioregional paradigm can be delineated by looking at Atkinson's theoretical contribution (1992). The world needs to adopt an entirely different mindset to achieve long-term development and sustainability. People need to rethink much of the basis of society, to decide what principles to implement and how restrictive they should be: "where do we draw the line?” (Atkinson, 1992, p. 331).

\section{METHODOLOGY}

This section is divided into two subsections. In the first one, we detailed the data collection and research material, while the second one focused on the data processing aspects.

The methodology is schematically depicted in Figure 1.

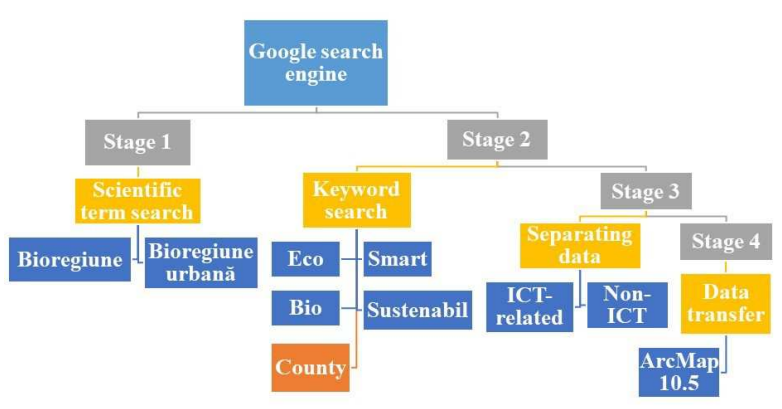

Fig. 1. Methodology scheme depicting our research process.

\subsection{Data collection and research material}

This study has been conducted exclusively by online keyword searching via the Google search engine, due to the imposed restrictions on mobility by the authorities in Romania during the COVID-19 pandemic. All the research material is based solely on online articles, as well as on public domains. This endeavour had several key stages presented below (see also Fig. 1 above).

During the first stage, we searched the internet using the two keywords in Romanian: "bioregiune" ["bioregion"] and "bioregiune urbană" ["urban bioregion"]. We searched for these terms in Romanian because we wanted to see if there was material on the topic/term in Romanian scientific literature and mass media. In the results section, initiatives regarding urban bioregions that were promoted in the online environment or that are strongly related to Information and Communication Technology (ICT) are presented.

During the second stage, which was the longest timewise, we searched the internet using four keywords, which we later used to create four categories. The keywords were "eco", "smart", "bio", and "sustenabil" [sustainable]. Next, we applied these keywords to all counties of Romania (Bucharest and Ilfov were merged because we thought they would be linked). Since our research was based on the default Google search engine and not on the Academic web, we felt those keywords would give us more potentially accurate results.

The thinking behind it was as follows: we searched for examples in each of the four categories we introduced. The formula of the keyword search was: eco/smart/bio/sustenabil + the name of the county. Example: eco + maramures (without special characters) = 99 results on 10 Google pages. We also kept track of how many pages we scrolled through and how many results for a final calculus.

We chose those four keywords because we had found them to prevail in pieces of online Romanian mass-media. The logic was that by having short keywords, they could be potentially included in longer 
wordings, so our search result would be larger. Also, by inserting the name of the county, instead of the county seat, we wanted to see as many results as possible, because most businesses, farms, start-ups, etc. have the address on their website, which almost always includes the county as well (another reason is that many counties share the name of the capital city, like Sibiu, Braşov, Arad, Galați, etc.).

We must specify that the four keywords are merely ways with which to find more sustainable practices. Since in the results section we will add them all, when they are separate, their value is just to show how many results one keyword search yielded. A biofarm could be classified as eco and vice versa, while a smart project could as well be sustainable. Therefore, when the reader sees, for example, the number 3 under "eco bucuresti", it only means that we found three relevant links by using those keywords. All categories contribute to the final number.

After searching by keywords, we would scroll through the pages and look at the headlines to see if they were related to our research on urban bioregions or not. If the headline appeared to relate to bioregional initiatives, we would click on the site and read the article. If the article was indeed accurate and adequate, we would note it down separately under the (example) "eco maramures" category. This process was repeated for all counties, four times (four keywords) for each, in order to accomplish our first objective, namely, to search for completed projects, active businesses, and implemented solutions across Romania.

A few particularities need to be mentioned. Firstly, upon finding an eco/bio farm, we would only include it if it had an online presence, either through a social media platform or its website. Furthermore, we would only include it if we could find a mention that their crops are eco/bio certified, or that they claim their food is natural (these last cases were rarer). Secondly, especially in terms of projects, we did not include funded but not started/not completed projects/initiatives, only the ones that were completed. Thirdly, we did not include ordinary firms/companies that every current society should have by default (example: street cleaning companies, waste collecting companies unless they were recycling, etc.). Fourthly, we did not include small student projects or minor events, especially those that were advertised as "awarenessraising" events, as we considered them not having as solid of an impact, because of their short period. Lastly, we did not include ongoing projects (especially if they were in the early stages), proposed projects, projects waiting to be financed, and so on. We did so because they were running the risk of never actually being completed. Therefore, we only wanted to construct a database with what was available at the moment of our research (the data collection was conducted between October 2020 and January 2021).

\subsection{Data processing}

The third stage meant looking again at every example found and separating them into non-ICT and ICT-related and creating a correlating table between county and keyword. As underlined in the introductory section, the assumption that bioregional oriented processes may be partly based on ICT tools adoption was realised in the context of the COVID-19 pandemic and encouraged by this, because of the lockdown and restricted mobility in Romania. Also, due to space restrictions in this article, non-ICT related initiatives were not included, but will be discussed in a future study. Separating examples into non-ICT and ICTrelated was the second objective of our paper, as presented in the results section. The final stage meant transferring the data into map format (via ArcMap 10.5), as well as analysing the overall results.

Those initiatives were divided depending on the historical region (Fig. 2) and depending on the development region² (Fig. 3) that they belonged to.

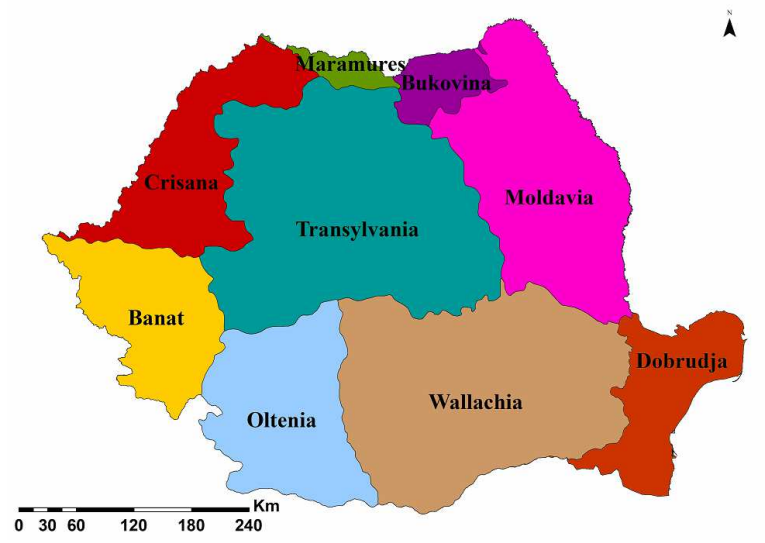

Fig. 2. Historical regions of Romania.

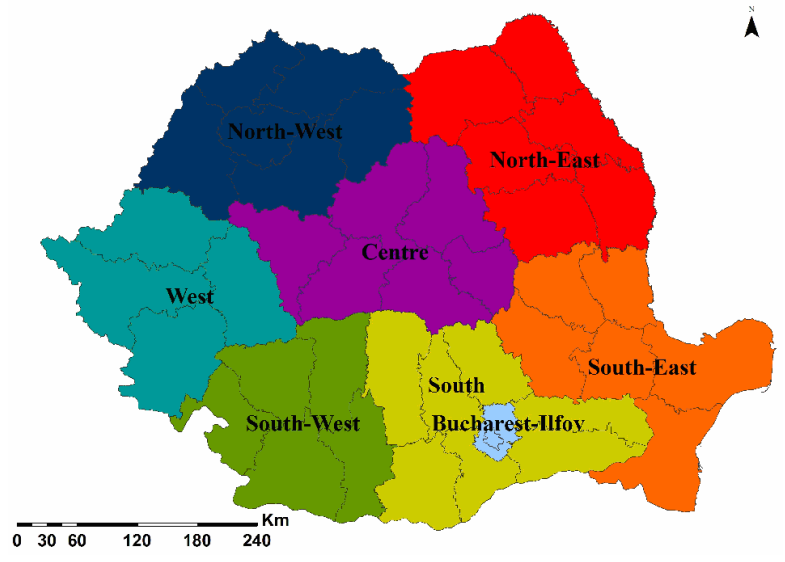

Fig. 3. Development regions of Romania.

${ }^{2}$ The historical regions of Romania are at present cultural regions, as perceived by Romanians, with no juridical attributes or development aims. In the past, they had been century-long historical provinces that later participated at the creation of the Romanian state, at the beginning of the $2 \mathrm{O}^{\text {th }}$ century. The territory of Romania was divided into eight development regions. These were set up in 1998 and are in fact statistical regions (NUTS 2 level in the European Union), with no juridical attributes. Their aim has been to coordinate regional development before and after Romania's joining the European Union. 
This approach was chosen to see on which level (administrative or historical/cultural) initiatives regarding urban bioregions had a more powerful application, because, even if administrative regions are officially used for (regional) development, people identify themselves with historical regions and their resources. Dividing the territory as mentioned above helped us accomplish our last objective, which was diagnosing Romania's territory. Every initiative that took place on the national level was counted separately and put into a section called "common initiatives".

Regarding the maps of the historical regions, we chose the following due to the availability of spatial data. These delimitations are nonetheless generally accepted among various Romanian scholars (Bărbulescu et al., 2002; Georgescu, 1992; Livezeanu, 1998). Romanian citizens often identify themselves with the historical regions. Although some may object to some demarcation lines or incorporations (for example, Satu Mare is often seen (1) as part of Crișana, (2) as part of Maramureş or (3) as its own crystalised historical region, separate from others), this decision has been made based on the availability of spatial data, and because each county is also analysed independently (readers will be able to visualise in detail nonetheless).

\section{RESULTS AND DISCUSSION}

We divided the results section into three major topics: the first on the situation of bioregional mentions on Romanian public websites (general, not scientific web), the second on the keyword-focused findings, and the third on an overview of sustainable development initiatives related to urban bioregional practices.

\subsection{Bioregion and urban bioregion keywords}

The keyword bioregiune [bioregion] displayed nine google pages and 90 links. Only two of them were related to our endeavour. The first was a scientific article by a Ph.D. candidate about the sustainability of balneal towns/resorts and coastal settlements (cf. Delcea, 2014). One of its keywords was bioregiune urbană [urban bioregion], although no other mention of the term was to be found in the text. The article, a snippet of a larger doctoral study, referred to how balneal-themed towns and cities need to achieve local auto-sustainability by creating a regional ecosystem. In other words, these settlements need to adapt to the current dynamic economy and enrich tourist offer by working with other nearby settlements or actors and promoting, alongside therapeutic balneal functions, heritage, leisure, nature, and other key strengths to achieve year-round fluxes of income. This, in turn, would reinforce territorial identity and long-term development (Delcea, 2014). No extended example or idea referred to the role of ICT in all of this. The other was a course material over 90 pages long, about 84 everything related to an eco-lifestyle: recycling, minimalist consumption, green activities, even ecohouse design (Baldea, 2015).

The keyword bioregiune urbană [urban bioregion] search displayed 120 results on 12 pages; however, only one was related to the topic. It was a complex 6o-page plan of governance for participative urban agriculture. The end goal for the Romanian partner was to fight social exclusion in the Danube area, while also promoting sustainable urban development. Titled "AgriGo4Cities", it was a transnational learning project lead by a Slovenian institutional actor (Szalók, Bende and Kozina, 2019). There was no major role of ICT in this pilot project that we could identify.

\subsection{Focused keyword searching: eco, smart, bio, sustenabil [sustainable]}

When analysing Table 1 , the reader will notice certain values depicted as follows: $1 / 0,4 / 3,5 / 4$, etc.

Table 1. Number of initiatives grouped by county and keywords.

\begin{tabular}{|c|c|c|c|c|c|}
\hline \multirow[b]{2}{*}{ Counties } & \multicolumn{5}{|c|}{ Keywords } \\
\hline & Eco & Smart & Bio & $\begin{array}{l}\text { Suste- } \\
\text { nabil* }\end{array}$ & Total \\
\hline Alba & 0 & 10 & 0 & 0 & 10 \\
\hline Arad & 1 & 2 & 2 & 0 & 5 \\
\hline Arges & 0 & 3 & 2 & 0 & 5 \\
\hline Bacău & $1 / 0$ & 0 & 1 & 0 & 1 \\
\hline Bihor & $4 / 2$ & 1 & $1 / 0$ & 0 & 3 \\
\hline Bistrița-Năsăud & 0 & 0 & $3 / 1$ & 0 & 1 \\
\hline Botoșani & 1 & 1 & 3 & 0 & 5 \\
\hline Brăila & 0 & 4 & 3 & 0 & 7 \\
\hline Brașov & $3 / 2$ & 2 & 7 & $2 / 1$ & 12 \\
\hline Buzău & 0 & 0 & 1 & 0 & 1 \\
\hline Călărași & 3 & 0 & $3 / 2$ & 0 & 5 \\
\hline Caraș-Severin & 0 & 1 & $2 / 1$ & 1 & 3 \\
\hline Cluj & 3 & 11 & $4 / 3$ & 3 & 20 \\
\hline Constanța & 0 & 0 & 0 & 0 & 0 \\
\hline Covasna & 0 & 1 & 0 & 2 & 3 \\
\hline Dâmbovița & 1 & 0 & 8 & 0 & 9 \\
\hline Dolj & $2 / 1$ & 0 & 1 & 0 & 2 \\
\hline Galați & 0 & 0 & 0 & 0 & 0 \\
\hline Giurgiu & $2 / 1$ & 0 & $3 / 2$ & 0 & 3 \\
\hline Gorj & 0 & 1 & $5 / 4$ & 0 & 5 \\
\hline Harghita & 1 & 3 & 2 & 0 & 6 \\
\hline Hunedoara & 8 & 3 & 3 & 1 & 15 \\
\hline Ialomița & 0 & 0 & 0 & 0 & 0 \\
\hline Iaşi & 1 & 8 & 4 & 1 & 14 \\
\hline Ilfov+Bucharest & 5 & 3 & $4 / 3$ & 3 & 14 \\
\hline Maramureș & 0 & 0 & 2 & 0 & 2 \\
\hline Mehedinți & 0 & 0 & 1 & 0 & 1 \\
\hline Mureș & 5 & 0 & $5 / 4$ & 1 & 10 \\
\hline Neamț & 2 & 0 & 0 & 0 & 2 \\
\hline Olt & 0 & 0 & 0 & 0 & 0 \\
\hline Prahova & 0 & 0 & 4 & 0 & 4 \\
\hline Sălaj & 5 & 2 & 2 & 0 & 9 \\
\hline Satu Mare & $3 / 2$ & 0 & 0 & 0 & 2 \\
\hline Sibiu & 0 & 2 & 3 & 1 & 6 \\
\hline Suceava & 0 & 0 & 1 & 2 & 3 \\
\hline Teleorman & 0 & 0 & $4 / 3$ & 0 & 3 \\
\hline Timiș & $4 / 3$ & 5 & $5 / 4$ & 3 & 15 \\
\hline Tulcea & $1 / 0$ & 2 & $1 / 0$ & 0 & 2 \\
\hline Vâlcea & 1 & 0 & 1 & 0 & 2 \\
\hline Vaslui & 2 & 0 & 1 & 0 & 3 \\
\hline Vrancea & 2 & 0 & 0 & 0 & 2 \\
\hline Romania & 52 & 65 & 79 & 19 & 215 \\
\hline
\end{tabular}


Those numbers indicate the number of bioregional practices found/ICT-related practices. When reading $4 / 3$, it means that although the county has 4 bioregional practices under one of the keywords, only 3 of them have an ICT component. A value with only 1 number means all practices have an ICT component. In Table 1, all initiatives were grouped depending on the keywords and county that they belonged to. The results were 215 initiatives related to ICT and the number of initiatives including those that were not related to ICT was $23(215+23=238$ total $)$.

In this section, we chose 15 examples of urban bioregional practices in Romania as short case studies. Those examples have been well promoted in the online environment, showing a strong relationship between ICT and urban bioregions. Considering those mentioned above, there were the following 15 initiatives: (1) "Ecoinsula", (2) "Ciugud Virtual Grocery", (3) "Food Waste Combat Cluj", (4) "Bee Happy", (5) "Bio Garden AMURTEL", (6) "The Vegetable Box", (7) “The Peasant's Box", (8) "Romanian Sea Buckhorn Plantations Ecologically Certified”, (9) "CUIB (Centrul Urban de Iniţiative Bune)" [Urban Centre of Good Initiatives], (10) "ECO-IT Bucureşti", (11) "DEPLIN organic cosmetics", (12) "Go Green, not Ego", (13) "Let's do it. Romania”, (14) "Discover EcoRomania", and (15) "Selective waste sorting”.

The first example is Ecoinsula [Ecoisland], an initiative of Braşov City Hall, Braşov's sanitation company, and EcoSmart Union S.A. (a company specialised in packaging waste and its management). This is a modern way to select the waste separately into categories such as paper, cardboard, plastic, glass, metal, and residual waste. This system weighs and recognises the person who selects the waste separately. It can be used only by citizens who live in residential units nearby this "island”. Braşov's sanitation company provides garbage bags with unique bar codes for all residents. Bar codes from garbage bags will be scanned and a door will open, depending on the category of waste (Ziarul Piața Presei, 2019).

Aprozarul Virtual Ciugud [Ciugud Virtual Grocery] is an initiative of the Ciugud Mayor's Office, created to promote local products, as well as local producers, and to develop the local economy. This idea came as an alternative after closing the agro-markets caused by the COVID-19 pandemic. Because of the pandemic situation, Ciugud Mayor's Office tried to determine and encourage people not to go to the nearest city to buy products. On the Ciugud Mayor's Office website, a virtual platform was created where all local producers and their products can be found. This is not a virtual platform where one can select and buy products instantly, instead one needs to select what products to buy and contact the local producer to discuss the quantity and price. Furthermore, the producers can be called or contacted using their Facebook page, if available. Because this was a smart idea of promoting local producers, on the platform, there were added producers from nearby communes. Even if this is not an urban area (though the commune is very close to Alba Iulia city), this is a good practice example that every urban area (and its surroundings) could apply (Primăria Comunei Ciugud, 2020).

Food Waste Combat Cluj is an NGO in Cluj-Napoca that fights food waste. This is considered one of the major problems of the modern world. The initiative works like a food bank, collecting the surplus of food from agricultural producers. After the food is collected, it is distributed to people in need. The donors can only be legal entities and beneficiaries should have legal personality (Food Waste Combat, 2018).

Bee Happy - Miere ecologică [Ecological Honey] is a company in Târgu Mureș that produces ecologically certified honey. The main line of activity is the preparation of honey specialities, but this company is different from other honey producers because they produce "cream honey specialties and other bee products, such as cocoa and mint honey cream, cinnamon honey cream, cranberry honey cream, dried fruit honey, and various seeds" (Fogarasi, 2019).

Bio Grădina AMURTEL [Bio Garden AMURTEL] is a bio certified farm in Buzău County which provides healthy, fresh, and eco vegetables for their customers. Everything is based on a vegetable box which changes weekly. What makes this initiative special from other bio-certified farms is that a bought vegetable box means caring for and providing money for eleven orphan children in the "Residential Centre AMURTEL Family", as well as putting fresh and healthy vegetables on their table (which is also the main aim of this initiative). Another interesting aspect is that those children can actively learn about nature and participate in growing and harvesting their own food (Gradina Bio AMURTEL, 2020).

Cutia cu legume [The Vegetable Box] consists of a pack of seasonal vegetables delivered by a family in Oinacu Commune, Giurgiu County, only to Bucharest and Ilfov County. The family that manages The Vegetable Box is helped by relatives that practice the same agricultural style, namely the traditional one, without chemicals. The content of the box cannot be chosen, it is fixed and changed depending on the season (Cutia cu legume, 2015).

Similar to the above-mentioned initiative is Cutia Țăranului [The Peasant's Box]. The difference between these two is that The Peasant's Box delivers not only to one big city but more, such as Arad, Brașov, Bucharest, Cluj-Napoca, Iași, Ploiești, Sibiu, Târgu Mureş, and Timişoara. In this case, there are families that practice agriculture in each county where the above-mentioned city lies, post advertisements about their products online, and sell them 
predominantly in urban areas. Like that of The Vegetable Box, the content of The Peasant's Box cannot be chosen, it is fixed and changed depending on the season (Cutia țăranului, 2017).

\section{Bio cătina [Romanian Sea Buckhorn} Plantations Ecologically Certified] is an agricultural cooperative and a good example of bioagriculture that takes place "in the Carpathian mountain arch, along the Argeș and Sașa rivers (Argeș and Vâlcea counties)" (Agricultural Cooperative Bio Cătina, 2019). The sea buckhorn plantations are ecologically certified by the Austrian Bio Guarantee (ABG). Even though agriculture is made using only organic substances, the farmers use modern technology such as reliable drip irrigation systems, state-of-the-art tractors, equipped with all the necessary accessories for fully mechanised soil maintenance (Agricultural Cooperative Bio Cătina, 2019). For this agricultural cooperative, the initiative represents the future of agriculture (for Romania), the two farmers investing in research and development. The products can be found in stores such as "Farmacia Gema", "Cărturești Verona" and "Cărturești Carusel" all three in Bucharest, "Curtea Brâncovenească" in Constanța, "Băcăniile Dasano" in Galați or can be found on various online platforms. We can notice that even though the products are grown in the regions of Oltenia and Muntenia, the products are sold not only locally, but also in regions like Moldavia, Dobrudja, as well as in the capital, Bucharest (Agricultural Cooperative Bio Cătina, 2019).

\section{CUIB (Centrul Urban de Iniţiative Bune)}

[Urban Center of Good Initiatives] is a restaurant and store in Iași City, in the historic region of Moldavia. The restaurant is different from others because it promotes ideas like water without plastic, food without meat, local and solidarity products, fair coffee and tea, natural juice, ecological wine, handcraft beer, discounts for bicyclists, and more environmentally friendly alternatives of consumption. All the ideas mentioned above seem to be beneficial for the environment because, until 2020, the restaurant decreased its carbon footprint by ten times in comparison with other social spaces. It stated that 11,000 plastic bags were saved from being discarded, and instead were recycled and reused. They also saved 23 million litres of water and over 1,300 animals (Centrul Urban de Iniţiative Bune, 2020). By 2023, CUIB aims to become the first restaurant and store in Romania certified Zero Waste, to reduce to the minimum the number of kilometres for supplying, to create a circular economy model for the HORECA 3 sector and to become the first food bank in Iași (Centrul Urban de Inițiative Bune, 2020).

ECO-IT Bucureşti is an initiative that aims to reuse IT products that were used for two or three

\footnotetext{
3 Acronym for the hospitality domain which includes hotels (HO), restaurants $(\mathrm{RE})$ and catering $(\mathrm{CA})$
} 86 years in the European Union office sector. This idea assumes importing IT equipment used in the European Union office sector, refurbishing, and selling it in Romania. Even if products are remanufactured, they are high quality, almost identical to new products. This is very beneficial to the environment, reducing possible pollution caused by this type of waste (Eco-IT București, 2015).

DEPLIN cosmetice organice [DEPLIN organic cosmetics] is a cosmetic company that uses high-quality bio certificated products. Furthermore, every ingredient is carefully selected and little processed to preserve as many of its natural benefits as possible. All organic ingredients used in production are Ecocert certified and have the best quality. Almost all raw materials are local products such as saffron oil, arnica, blackcurrant, hemp, chamomile, rosemary, ivy, sea buckthorn, and red grape extract (DEPLIN cosmetice organice, 2021).

Go Green, not Ego - traininguri de educație ecologică [Go Green, Not EgoTrainings for Ecological Education] is a project which addresses the problem of polluting natural resources in Bihor County such as green spaces, freshwater resources, public parks, etc. This project aims to underline the importance of an ecological and sustainable life among young people. The team that manages the project intends to train 66 young people, during 16 face-to-face meetings and 50 online meetings and teach them about the problem of intense pollution in Bihor's natural environment (Cotidian Independent Crișana, 2020).

Let's Do It, Romania! is a national campaign that takes place every year on the $23^{\text {rd }}$ of September, during World Cleaning Day. Every year those interested in making a change are called to clean the garbage from the surroundings. Local authorities support the volunteers by bringing gloves and garbage bags. Volunteers are promoted in the online environment (such as the official Facebook Page of Let's do it, Romania, or the City/Town Hall Facebook Pages) as good citizens. The only reward for participating in this initiative is that the environment is cleaner, and people took part in this step (Neacșu, 2019).

Descoperă Eco-România [Discover EcoRomania] is an initiative by the Ecotourism Association of Romania, which promotes ecotourism in "eco destinations" from the whole country (Descoperă Eco-România, 2020). According to the Ecotourism Association of Romania, ecotourism "is a form of tourism where the main motivation of tourists is observing and appreciating the nature and local traditions related to nature" (Descoperă Eco-România, 2020). The best part of this initiative is that ecotourism contributes in a positive way to the preservation of natural areas. Tourists take part in the conservation of the visited natural areas, offering constructive ways for 
the management of natural areas such as financial help for reconstructing them or collecting the waste littered by other tourists that did not respect nature. Examples of eco destinations are Eco Maramureș, Țara Dornelor [The Land of the Dornas], the Danube Delta, Mărginimea Sibiului, Țara Hațegului [The Land of Hațeg]-Retezat, Colinele Transilvaniei [The Transylvanian Hills], etc. (Descoperă Eco-România, 2020).

The last aspect that we discuss is not an initiative, but rather a law on selective waste sorting. It was adopted in 2019 and enforces sorting waste into four categories: Green: glass, Yellow: plastic and metal, Blue: paper and cardboard, Black or Brown: wet fraction (Parlamentul României, 2019).

\subsection{An overview of initiatives related to urban bioregional practices}

It is obvious that many southern Romanian counties (which overlap the fertile Danubian Plain), as well as other counties with more arable (and fertile) land, have a greater concentration of bio/eco-oriented initiatives (Fig. 4).

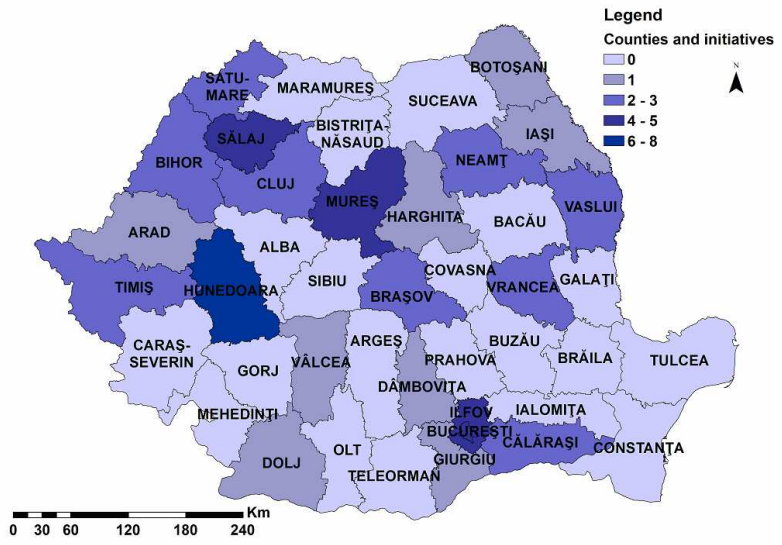

Fig. 4. "Eco" keyword search results.

Prime examples are Hunedoara, Timiș, Mureș, Cluj, Sălaj, Bihor, and especially Dâmbovița. Dâmbovița has many eco/bio-certified farms, benefiting, like the rest of the southern examples, from both very fertile land, accessible prices, and proximity to Bucharest, where they can create a short food chain (for short food chains in Romania, cf. Havadi-Nagy, 2021). It is the same with Arad, Sibiu, Brașov, and Mureș, each having several smaller or larger farms, selling their products to the main cities (and of course, outside of the county, by courier). Therefore, we can confidently state that the second hypothesis (counties with more arable land will have more farming-oriented approaches) is validated. These counties are those situated mainly in the lowlands of Romania.

While researching and building the database, we found out that the more urbanised the county was (i.e. more cities), the more smart projects/business there were to be found (Fig. 5).

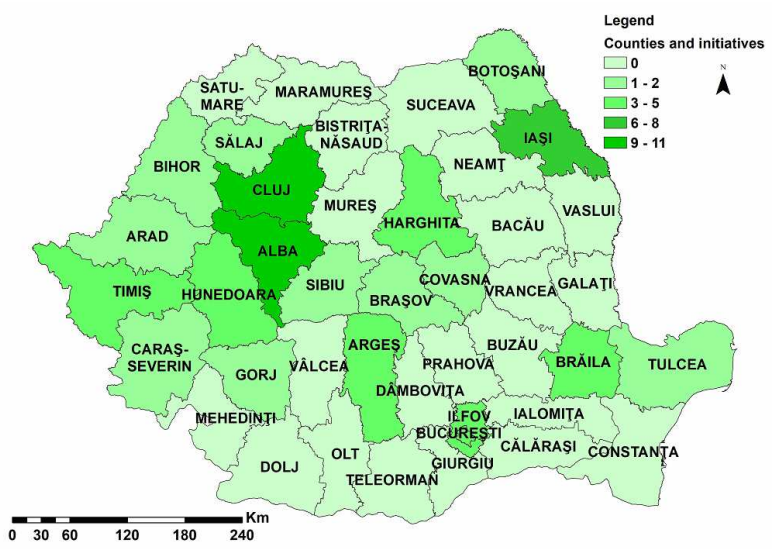

Fig. 5. "Smart" keyword search results.

This is obvious for the four regional capitals (Bucharest, Iaşi, Cluj-Napoca, and Timişoara), but it is also true for cities such as Turda, Dej, Sibiu, Brașov, and Mioveni. Mioveni has implemented a smart-city pilot project in partnership with Chinese investors (Sărărescu, 2019). Therefore, our third hypothesis (initiatives in Romanian cities will mainly be smartoriented) is validated.

A few of the notable aspects we noticed while researching was that most bio-related searches (Fig. 6) were not eco/bio-certified farms, but rather large commercial online/offline markets that sold imported bio-products, such as cocoa, cocos, exotic herbs, etc.

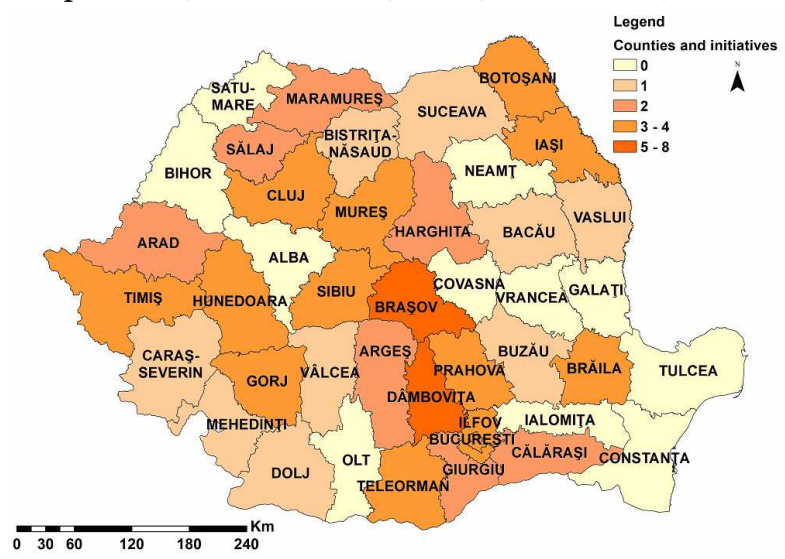

Fig. 6. "Bio" keyword search results.

Although bio/eco-certified it is debatable whether these large supply chains leave a big carbon footprint because of the large traveling distance of the commercialised products, as literature is not providing an established result about this so far (cf. Loiseau et al., 2016; Malak-Rawlikowska et al., 2019). Also, when typing smart, most first page results were markets of buying/selling smart vehicles.

Sustainable is not so commonly found in articles and searches (Fig. 7), especially outside of the major cities. We believe this shows how much of an infant the sustainable development paradigm is in Romania. It is mandatory that the bioregional paradigm initiatives irradiate more into the territory of Romania, 
to avoid negative consequences linked to the opposite (i.e an unsustainable society defined by voracious consumerism, relying on fossil fuel, that wastes a lot of resources, hostile towards the environment, etc.).

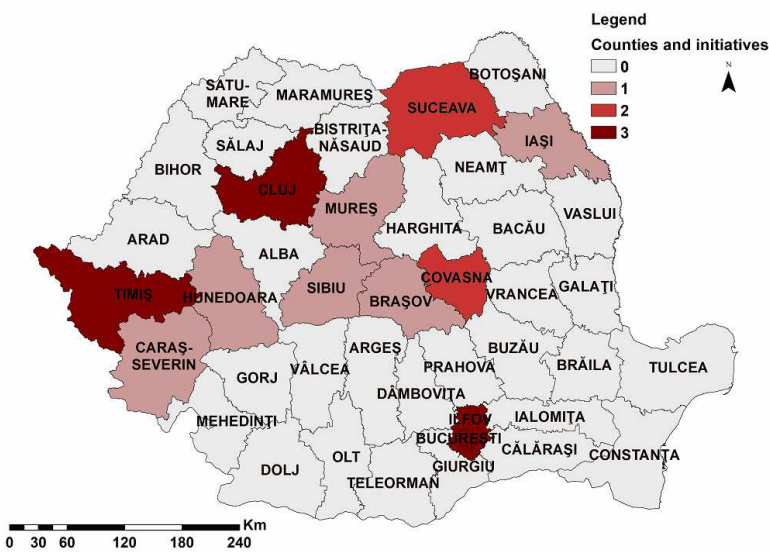
result.

As theory suggests, uneven civic engagement and (bio)regional development across space (Fig. 8) may lead to migratory movements from less (green) developed regions to the more stable, prosperous, main centres (Ayres, 2018).

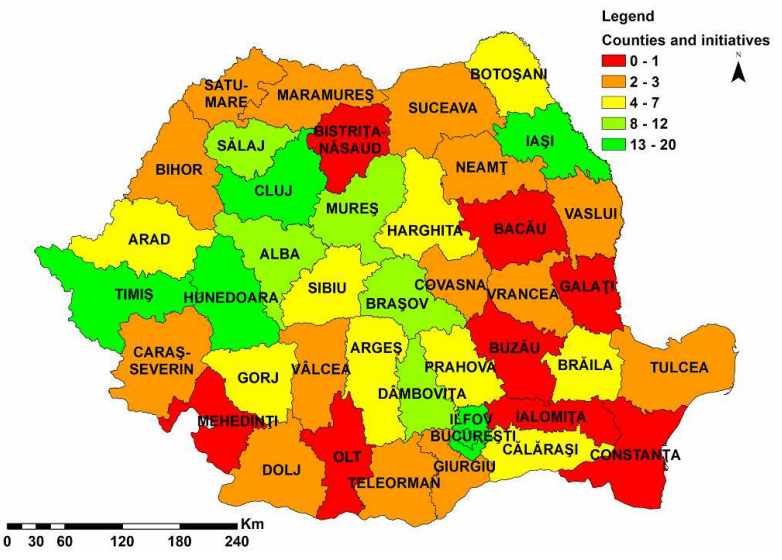

Fig. 8. Total number of initiatives per counties from all keywords (eco, smart, bio, sustainable).

As mentioned in the Methodology section, all initiatives were sorted in tables depending on the originating region (i.e. historical or development region). We underline that initiatives that take place at the national level were placed in a different section entitled "common initiatives" (Table 2 and Table 3 ) and were not included as initiatives for all regions.

When we discuss initiatives considering historical regions (Table 2), Transylvania leads: this region is better represented in terms of initiatives than others. Of the nine historical regions, Transylvania and Wallachia account for the most initiatives. Regionally speaking, we noticed that richer in initiatives was Transylvania, in terms of eco/bio, smart and sustainable online search-based results, while especially Wallachia was rich in bio/eco online search-based results.
Bukovina, Oltenia, Maramureş, and Dobrudja were, by comparison, lacking, and we can notice that even by comparing Iași to Mureș or Dâmbovița. Therefore, we can already see territorial inequality. We believe this may be due to several reasons.

Table 2. Historical regions and number of initiatives.

\begin{tabular}{c|lc} 
No. & \multicolumn{1}{|c}{ Historical region } & $\begin{array}{c}\text { No. of } \\
\text { initiatives }\end{array}$ \\
\hline 1 & Transylvania & 92 \\
2 & Banat & 18 \\
3 & Crisana & 10 \\
4 & Maramures & 2 \\
5 & Bukovina & 3 \\
6 & Moldavia & 25 \\
7 & Dobrudja & 2 \\
8 & Wallachia & 53 \\
9 & Oltenia & 10 \\
10 & Common initiatives/National level & 10
\end{tabular}

Table 3. Development regions and number of initiatives.

\begin{tabular}{c|lc} 
No. & \multicolumn{1}{|c}{ Development region } & $\begin{array}{c}\text { No. of } \\
\text { initiatives }\end{array}$ \\
\hline 1 & North-East & 28 \\
2 & South-East & 12 \\
3 & South & 29 \\
4 & South-West & 10 \\
5 & West & 38 \\
6 & North-West & 37 \\
7 & Centre & 47 \\
8 & Bucharest-Ilfov & 14 \\
9 & Common initiatives/National level & 10
\end{tabular}

Among these, there are a lack of infrastructure, less commercial ties and connections, and lack of developed national neighbours. We cannot affirm that there is a difference due to a historical better mentality in the western areas, because there are notable initiatives in Moldova and Wallachia as well. What can be stated, irrelevant of the regions, is that a number of start-ups, eco-farms, businesses have been founded by people owning a high-education degree, entrepreneurial knowledge, or having family tradition (meaning that one or more past generations, usually the parents and grandparents, activated in the same field).

Large cultural, social, and economic centres, such as Bucharest (Wallachia), Cluj (Transylvania), Iași (Moldavia), and Timiș (Banat) concentrate initiatives, exactly as theory suggests (cf. Asheim, 2018), partially validating our first hypothesis (counties with more population (and also higher population density) will have more initiatives, and their number is based on the general development level.

The four main centres of Romania Bucharest, Cluj-Napoca, Iași, Timișoara - have the most initiatives. However, the number of people does not seem to correlate with the number of initiatives. There were other factors (see above), probably multiple, which led to the implementation of more bioregional practices. 
In the case of the development regions (Table 3), initiatives seem to be more equally distributed. This is happening because Transylvania, the region with the highest number of initiatives among historical regions, has its counties divided among three development regions, namely the West, North-West, and Centre. The North-East region is made up of the historical regions of Bukovina and Moldavia, those two regions counting exactly 28 initiatives. The highest number of initiatives by development regions are in those that are more developed, not quite those regions that have the largest surface, this being the case of West, North-West, and Centre regions. The West Region is the smallest of them all (by surface and number of inhabitants), including only four counties, but it has two counties that count 15 initiatives each (Hunedoara and Timiş).

Considering the results in Table 2 and Table 3, we argue that initiatives regarding urban bioregions are more equally distributed in development regions in comparison to historical regions, where Transylvania seems to be the cluster of initiatives in Romania. The initiatives, although more than 200, are punctiform in size and scope.

Currently, as far as we know, there is no topdown coordinated major plan to rethink Romania (with concrete projects) in accordance with the bioregional paradigm (apart from the 2030 Strategy for Development, cf. Guvernul României, 2018, which is more of a theoretical guide). Most initiatives emerge from the local and regional scale and are implemented at those same scales. Therefore, we consider the fourth hypothesis validated (initiatives will be more punctiform than larger scale, signalling that Romania is only just starting its process of becoming greener/eco/smart/sustainable).

\section{CONCLUSIONS}

The results of this article point to a rather underwhelming reality. Romania has a long road ahead to become a sustainable territory. The cities of Romania, although moderately rich in such initiatives, are not even remotely close to setting a trend in bioregional practices. At most, they are fledgling organisms that need a lot more work, dedication, vision, and funding to (hopefully) reach some of the objectives of the bioregional paradigm and sustainable development.

Furthermore, Romania shows that even after 30 years of democratic development, with EU funding since 2007, and numerous local efforts, it still suffers from significant economic and social inequalities, and this aspect is visible even in the potential of reaching the aims of the bioregional paradigm. Further focus on small towns (there are 225 small towns, with under 20,000 inhabitants, accounting for $70 \%$ of the Romanian urban system) could aim to tackle their uneven development (cf. Stoica et al., 2020, p. 843), by specific policies where urban regional practices could find their place.

Most of the urban bioregional initiatives are focused on agriculture. Agriculture is a domain wellfunded with EU contribution, aiming nowadays to support traditional methods without using chemicals (bio-agriculture). Romania has a big advantage in comparison to other European countries, because of the large surface that can be used for agriculture. The European Union is supporting sustainable traditional agricultural practices and Romania's agriculture is based, for the most part, on this type (cf. also HavadiNagy, 2021). The strength of Romania's agriculture is not only the quantity but the quality of its products. Furthermore, selling products can take a new shape, in the sense that products can start being sold online if there are possibilities (internet connection, online customers, online promotion, ways of transporting products in different places, etc.).

The abundance of businesses in the eco/bio farming sector shows, at least, that Romanians in general wish to eat healthier and be closer to nature. The smart initiatives show that they want to be more connected and simplify their lives. It is, in our opinion, a start. The recent pandemic will probably enable a faster spread of ICT-related initiatives. In the future, more initiatives will probably emerge in Romania.

The current pandemic demonstrated the fragility of large urban concentrations and the limitations of over-relying on a global web of supply connections. Historically, the Romanian territory was dominated by umbilical relationships between the urban and rural spaces. Today, this link has still not been completely severed, and we believe this to be an adequate frame for the (re)emergence of more intimate development strategies. To us, the current international discourses on sustainability coupled with suitable policies and practices in the territorial context of our country could create a nursery for (urban) bioregional thought and action.

Several limitations hindered this study's focus and thoroughness. Firstly, online-only documentation means we could not investigate "offline", to see some of these initiatives for ourselves. Secondly, our research results were limited to the four keywords and county names. Surely, another keyword combination may have yielded more results, unknown at this point. Finally, even though we thoroughly analysed the resulted pages and links, we cannot affirm that at least a few did not elude us, due to fatigue, speed of scrolling, or just because of misleading titles.

Acknowledging the limitations of this research, we consider this study to be revealing for the current situation of bioregional initiatives in Romania. It is clear from our tables and maps that the major economic centres pave the way towards a greener and smarter 
future, so the next researchers to start working in this direction can use the information presented to compare and have a mental footnote of the situation.

\section{ACKNOWLEDGEMENT}

This research was realised based on activities within a fellowship held by Associate Professor OanaRamona Ilovan, Ph.D., and implemented in SeptemberOctober 2020, with the project titled: Bioregiuni urbane. Rolul TIC în regenerarea environmentală, socială şi economică [Urban Bioregions. The Role of Information and Communication Technology in Environmental, Social and Economic Regeneration]. It was funded by STAR-UBB Institute (The Institute of Advanced Studies in Science and Technology) within an Advanced Internal Fellowship (didactic excellence informed by scientific research), part of the project 33PFE/2018 (Strategic infrastructure at Babeş-Bolyai University in the context of developing new and smart technology - 2018-2020).

\section{REFERENCES}

Ackerman-Leist P. (2013), Rebuilding the Foodshed. How to Create Local, Sustainable, and Secure Food Systems. ISBN 978-1-60358-423-4.

Agricultural Cooperative Bio Cătina (2019), Romanian Sea Buckhorn Plantations Ecologically Certified. URL: http://biocatina.com/welcome/. Accessed on 7.01.2021.

Asheim T. B. (2018), Learning regions-a strategy for economic development in less developed regions? In: Paasi A., Harrison J., Jones M. (eds.), Handbook on the Geographies of Regions and Territories. Edward Elgar Publishing, Cheltenham (UK), Northampton (USA), 130-140.

Atkinson A. (1992), The urban bioregion as 'sustainable development' paradigm. Third World Planning Review, 14(4), 327-354.

Avadhanulu J. V. (2011), Integrated Communication and IT Infrastructure (ICITI) for the socio-economic development of Auroville bioregion. Proceedings of the Asia-Pacific Advanced Network, 32, 172-184. DOI: http://dx.doi.org/10.7125/APAN.32.21.

Ayres S. (2018), Regional governance and democracy. In: Paasi A., Harrison J., Jones M. (eds.), Handbook on the Geographies of Regions and Territories. Edward Elgar Publishing, Cheltenham (UK), Northampton (USA), 219-230.

Baldea M. (2015), Tendințe actuale în amenajări curs 3 eco/verde [Present Trends in Arrangements Lecture $\quad 3 \quad$ Eco/Green]. URL: https://issuu.com/majabaldea/docs/tendinte_actuale_ curs_3_-_eco. Accessed on 6.01.2021.

Banini T., Ilovan O.-R. (2021a), Conclusions: towards a new agenda for place/territorial identity research. In: 90
Banini T., Ilovan O.-R. (eds.), Representing Place and Territorial Identities in Europe. GeoJournal Library, vol. 127. Springer, Cham, 251-265. DOI: https://doi.org/10.1007/978-3-030-66766-5_17.

Banini T., Ilovan O.-R. (2021b), Introduction: dealing with territorial/place identity representations. In: Banini T., Ilovan O.-R. (eds.), Representing Place and Territorial Identities in Europe. GeoJournal Library, vol. 127. Springer, Cham, 1-19. DOI: https://doi.org/10.1007/9783-030-66766-5_1.

Bărbulescu M., Deletant D., Hitchins K., Papacostea Ș., Teodor P. (2002), Istoria României [History of Romania]. Corint, Bucharest. [Book in Romanian]. ISBN 978-973-135-686-0.

Bibri S. E. (2019), On the sustainability of smart and smarter cities in the era of big data: an interdisciplinary and transdisciplinary literature review. Journal of Big Data, 6(25), 1-64. DOI: https://doi.org/10.1186/s40537019-0182-7.

Centrul Urban de Inițiative Bune [Urban Centre of Good Initiatives] (2020), Acasă [Home]. URL: https://incuib.ro/. Accessed on 7.01.2021.

Church S. P. (2015), Exploring urban bioregionalism: a synthesis of literature on urban nature and sustainable patterns of urban living. S.A.P.I.E.N.S: Surveys and Perspectives Integrating Environment and Society, 7(1), 1-11.

Cotidian Independent Crișana [Crișana Independent Newspaper] (2020), Go Green, Not Ego-Traininguri de educație ecologică [Go Green, Not Ego-Trainings for Ecological Education]. URL: https://www.crisana.ro/stiri/educa-ie-6/go-green-notego-traininguri-de-educatie-ecologica-178712.html.

Accessed on 7.01.2021.

Cutia cu legume [The Vegetable Box] (2015), Cutia cu legume - legume proaspete şi de sezon, produse în mod tradiţional, livrate la uşa ta! [The Vegetable Box - Fresh Season Vegetables, Traditionally Produced, Delivered at Your Door!] URL: https://cutiaculegume.ro/. Accessed on 6.01.2021.

Cutia ţăranului [The Peasant's Box] (2017), Țăranii români livrează hrană prospătă, crescută local, direct la ușa dumneavoastră [The Romanian Peasants Deliver Fresh Local Food Directly to Your Door]. URL: https://cutiataranului.ro/. Accessed on 6.01.2021.

Delcea I. (2014), Sustenabilitate locală și reteritorializare. Revizitarea proiectului de oraş balnear [Local sustainability and re-territorialisation. Revisiting the balneal resort project]. Argument. Studii și cercetări ştiinţifice de arhitectură şi urbanism, 6, 299-317.

DEPLIN cosmetice organice [DEPLIN organic cosmetics] (2021), Cosmetice naturale de care să te bucuri în fiecare zi [Natural Cosmetics for You to Enjoy Everyday]. URL: https://www.deplin.ro/ro. Accessed on 6.01.2021.

Descoperă Eco-România [Discover EcoRomania] (2020), Redescoperă România. Există zone 
spectaculoase în România care merită descoperite [Discover Romania Again. There Are Spectacular Areas in Romania That Deserve to Be Discovered]. URL: https://www.eco-romania.ro/. Accessed on 7.01.2021.

Drepaul N. A. (2020), Sustainable cities and the Internet of Things (IOT) technology. Consilience. The Journal of Sustainable Development, 22, 39-47. DOI: https://doi.org/10.7916/consilience.vi22.6742.

Eco-IT București (2015), ECOIT. URL: http://www.eco-it.ro/. Accessed on 7.02.2021.

Entrikin N. J. (2018), Geography of experience: place and region. In: Paasi A., Harrison J., Jones M. (eds.), Handbook on the Geographies of Regions and Territories. Edward Elgar Publishing, Cheltenham (UK), Northampton (USA), 44-56.

Fanfani D., Duží B. (2019), Urban bioregion concept: from theoretical roots to development of an operation framework in the European context. Atti della XXI Conferenza Nazionale SIU - Società Italiana degli Urbanisti "Confini, movimenti, luoghi. Politiche e progetti per città e territori in transizione. Firenze 6-8 giugno 2018”, 44-52. URL: https://www.researchgate.net/publication/338127221_ Urban_bioregion_concept_from_theoretical_roots_to _development_of_an_operational_framework_in_the _European_context. Accessed on 17.12.2020.

Fanfani D. (2020), The co-evolutionary recovery of the urban/rural interface: policies, planning, and design issues for the urban bioregion. In: Fanfani D., Matarán Ruiz A. (eds.), Bioregional Planning and Design: Vol I. Cham, Springer, 129-150.

Filip S. (2009), Planning urban [Urban Planning]. Presa Universitară Clujeană, Cluj-Napoca. [Book in Romanian]. ISBN 978-973-610-956-0.

Fogarasi S. (2019), Bee Happy. URL: https://beehappy.ro/despre-noi/. Accessed on 16.02.2021. Food Waste Combat (2018), Acasă [Home]. URL: https://foodwastecombat.com/. Accessed on 24.10.2020.

Georgescu V. (1992), Istoria românilor. De la origini pînă în zilele noastre [History of Romanians. From Origins to Nowadays]. Humanitas, Bucharest. [Book in Romanian]. ISBN 978-973-280-548-0.

Gheorghiu T. O. (2009), Așezări umane. Repere teoretice și istoria timpurie a Orientului Apropiat [Human settlements. Theoretical landmarks and the early history of the Middle East], vol. 1. Editura Artpress, Timişoara. [Book in Romanian]. ISBN 978973-108-191-5.

Gibbs D. (2018), Sustainable regions. In: Paasi A., Harrison J., Jones M. (eds.), Handbook on the Geographies of Regions and Territories. Edward Elgar Publishing, Cheltenham (UK), Northampton (USA), 182-194.

Global e-Sustainability Initiative, Collaborating Centre on Sustainable Consumption and Production (GeSI, CSCP) (2012), Workstudio. Future lifestyles and opportunities for the ICT industry. Envisioning pathways towards sustainable living in 2050. URL: $\quad$ http://www.gesi.org/research/download/33. Accessed on 6.01.2021.

Gradina Bio AMURTEL (2020), Coşul de legume bio: proaspăt, în siguranță, local [The Bio Vegetable Basket: Fresh, Safe, Local]. URL: https://legumeeco.ro/ro/. Accessed on 7.01.2021.

\section{Guvernul României [Government of Romania]} (2018), Strategia Naţională pentru Dezvoltarea Durabilă a României 2030 [National Strategy for the Sustainable Development of Romania 2030]. URL: https://www.edu.ro/sites/default/files/Strategianationala-pentru-dezvoltarea-durabila-a-României2030.pdf. Accessed on 18.02.2021.

Hammond G. P., Iddenden T., Wildblood J. (2017), Environmental and resource burdens associated with an urban community and its surrounding bioregion. $1^{\text {st }}$ Joint Conference on World Engineers Summit - Applied Energy Symposium \& Forum: Low Carbon Cities \& Urban Energy Joint Conference, WESCUE 2017, 19-21 July 2017, Singapore, 143, 481-486. DOI: https://doi.org/10.1016/j.egypro.2017.12.714.

Harris G., Nixon D., Newman L., Mullinix K. (2016), Delineating the Southwest British Columbia bioregion for food system design and planning: a practical approach. Journal of Agriculture, Food Systems, and Community Development, 6(4), 71-86. DOI: http://dx.doi.org/10.5304/jafscd.2016.064.010.

Hartel T., Fischer J., Câmpeanu C., Milcu A. I., Hanspach J., Fazey I. (2014), The importance of ecosystem services for rural inhabitants in a changing cultural landscape in Romania. Ecology and Society, 19(2), 42. DOI: http://dx.doi.org/10.5751/ES-06333190242.

Havadi-Nagy K. X. (2021), Alternative food networks in Romania - effective instrument for rural development? Journal of Settlements and Spatial Planning, Special Issue Territorial Identities and Sustainable Development. Challenges and Solutions, 8, 15-27. DOI: 10.24193/JSSPSI.2021.8.03.

Havadi-Nagy K. X., Ilovan O.-R., Damyanovic D., Reinwald F., Mărginean M. (2017), Advocacy for participatory rural development. A comparison of two case studies from Romania and Austria. In: Jordan P. (ed.), New Developments in the Rural Space of Central and South-East Europe. Proceedings of the meeting of the Working Group on Central Europe in conjunction with the German Congress of Geography, Berlin, September 30, 2015. HEFT 43. Verlag der Österreichischen Akademie der Wissenschaften, Wien, 121-15O. DOI: 10.1553/ISR_FBo43.

Hedden W. P. (1929), How Great Cities Are Fed. Boston, New York D.C., Heath and Co.

Huggins R., Thompson P. (2018), Regional innovation and growth theory: behavioral and institutional approaches. In: Paasi A., Harrison J., 
Jones M. (eds.), Handbook on the Geographies of Regions and Territories. Edward Elgar Publishing, Cheltenham (UK), Northampton (USA), 116-129.

Ilovan O.-R., Ciupe I. A. (2021), Urban Bioregions. Discourses and Practices in Romania. Presa Universitară Clujeană, Cluj-Napoca, forthcoming.

Ilovan O.-R., Ciupe I. A., Marin M. (2021), Sustainable urban-rural relationships in Romania within the paradigm of urban bioregionalism. In: Colavitti A.M. (ed.), Building the Urban Bioregion. Governance Scenarios for Urban and Territorial Planning (Collana Studi e ricerche territorialisti diretta da F. Schilleci), forthcoming.

Ilovan O.-R., Dulamă M. E., Marin M., Răcăşan B. S., Egresi I., Havadi-Nagy K. X., Mutică P. (2021), Online documentation for emerging subjects in geographical research: the urban bioregion. In: Albulescu I, Stan N.-C. (eds.), $8^{\text {th }}$ Edition of Education Reflection Development International Conference 2020, European Proceedings of Social and Behavioural Sciences, 104, 268-281. DOI: 10.15405/epsbs.2021.03.02.29.

Ilovan O.-R., Havadi-Nagy K. X., Botezat I., Caranfil R.-A. (2020a), Susţinerea rezilienţei urbane prin practici de regenerare în oraşe dinamice din areale periferice. Studiu de caz: Cluj-Napoca [Supporting urban resilience through regeneration practices in dynamic cities of peripheral areas. Case study: ClujNapoca]. In: Ilovan O.-R. (ed.), Rezilienţă şi dezvoltare durabilă [Resilience and Sustainable Development]. Cluj-Napoca, Presa Universitară Clujeană, 59-109.

Ilovan O.-R., Havadi-Nagy K. X., Păcurar B., Dulamă M. E., Jucu I. S., Simioană M., Koszinski S. A. (2020b), Learning from the experts: Liberty Technology Park - investment, innovation, development. In: Chiș V. (ed.), $7^{\text {th }}$ Edition of Education Reflection Development International Conference 2019, European Proceedings of Social and Behavioural Sciences, $\quad 85, \quad 242-252$. DOI: 10.15405/epsbs.2020.06.24.

Ilovan O.-R., Jordan P., Havadi-Nagy K. X., Zametter T. (2016), Identity matters for development. Austrian and Romanian experiences. Transylvanian Review, XXV(Supplement 1), 261-276.

Ilovan O.-R., Măgeruşan A., Boţan C. N., Dulamă M. E., Ursu C.-D., Mutică P., Jucu I. S. (2020c), Experiencing and bringing back the river in the urban flow: Someş Delivery. In: Chiş V. (ed.), $7^{\text {th }}$ Edition of Education Reflection Development International Conference 2019, European Proceedings of Social and Behavioural Sciences, 85, 262-272. DOI: 10.15405/epsbs.2020.06.26.

Ilovan O.-R., Maroși Z., Dulamă M. E., Scridon I., Boțan C. N., Fonogea S. F., Rus G.-M. (2020d), Learning from practice in the Paintbrush Factory: revival through art. In: Chiș V. (ed.), $7^{\text {th }}$ Edition of Education Reflection Development International 92
Conference 2019, European Proceedings of Social and Behavioural Sciences, 85, 253-261. DOI: 10.15405/epsbs.2020.06.25.

Ilovan O.-R., Medeşan S., Colcer A.-M., Adorean E.-C., Dulamă M. E., Cîineanu M.-D., Benedek R. (2020e), Raising civic awareness and involvement through urban regeneration: At the Playgrounds, Mănăştur. In: Chiş V. (ed.), $7^{\text {th }}$ Edition of Education Reflection Development International Conference 2019, European Proceedings of Social and Behavioural Sciences, $\quad 85, \quad 273-281 . \quad$ DOI: 10.15405/epsbs.2020.06.27.

Jones A. (2018), Economic regionalization. In: Paasi A., Harrison J., Jones M. (eds.), Handbook on the Geographies of Regions and Territories. Edward Elgar Publishing, Cheltenham (UK), Northampton (USA), 105-115.

Kloppenburg J., Hendrickson J., Stevenson G. W. (1996), Coming into the foodshed. Agriculture and Human Values, 13(3), 33-42. DOI: 10.1007/BFo1538225.

Kobulniczky B., Ilovan O.-R. (2020), Forum theatre - assessing openness to temporary participatory use practices of the Someșul Mic River area in ClujNapoca, Romania. Dela, 53, 111-129. DOI: 10.4321/dela.53.111-129.

Kumar S. (2020), An overview of smart city approaches for addressing global climate crisis. International Research Journal of Science Engineering and Technology, 10(4), 6-11.

Livezeanu I. (1998), Cultură şi nationalism în România Mare 1918-1930 [Culture and Nationalism in Greater Romania 1918-1930]. Humanitas, Bucharest. [Book in Romanian]. ISBN 978-973-280-865-8.

Loiseau E., Saikku L., Antikainen R., Droste N., Hansjürgens B., Pitkänen K., Leskinen P., Kuikman P., Thomsen M. (2016), Journal of Cleaner Production, 139, 361-371. DOI: https://doi.org/10.1016/j.jclepro.2016.08.024.

Magnaghi A. (2014), La biorégion urbaine. Petit traité sur le territoire bien commun. Paris, Eterotopia France/rhizome. ISBN 979-10-93250-00-7.

Magnaghi A. (2020), The territorialist approach to the urban bioregion. In: Fanfani D., Matarán Ruiz A. (eds.), Bioregional Planning and Design: Vol I. Cham, Springer, 33-61.

Malak-Rawlikowska A., Majewski E., Wąs A., Borgen S. O., Csillag P., Donati M., Freeman R., Hoàng V., Lecoeur J.-L., Mancini M. C., Nguyen A., Saïdi M., Tocco B., Török Á., Veneziani M., Vittersø G., Wavresky P. (2019), Measuring the economic, environmental, and social sustainability of short food supply chains. Sustainability, 11(15), 4004. DOI: https://doi.org/10.3390/su11154004.

National Geographic Encyclopedia (2020), Urban Areas. URL: https://www.nationalgeographic.org/encyclopedia/urb 
an-

area/\#: :text=An\%20urban\%20area\%20is\%20the\%20 region\%20surrounding\%20a\%20city.,towns\%2C\%20cit ies\%2C\%20and\%20suburbs. Accessed on 24.10.2020.

Neacşu M. (2019), Let's Do It, Romania! 2009-2019 Rezultatele acţiunilor noastre şi ce ne-a motivat să revenim [Let's Do It, Romania! 2009-2019 Results of Our Actions and What Made Us Come Back]. URL: https://blog.letsdoitromania.ro/uncategorized/lets-doit-romania-2009-2019-rezultatele-actiunilor-noastresi-ce-ne-a-motivat-sa-revenim/. Accessed on 24.10.2020.

Parlamentul României [Parliament of Romania] (2019), Legea 31/2019 privind aprobarea Ordonanţei de urgenţă a Guvernului nr. 74/2018 pentru modificarea şi completarea Legii nr. 211/2011 privind regimul deşeurilor, a Legii nr. 249/2015 privind modalitatea de gestionare a ambalajelor şi a deşeurilor de ambalaje şi a Ordonanţei de urgenţă a Guvernului nr. 196/2005 privind Fondul pentru mediu [Law $31 / 2019$ on approving the Urgent Governmental Ordinance no. 74/2018 concerning the change and completion of the Law no. 211/2011 on the waste, of the Law no. 249/2015 concerning management of packages and their waste and of the Urgent Governmental Ordinance no. 196/2005 on the Environmental Fund]. URL: http://www.ecoteca.ro/wpcontent/uploads/2019/01/2019_L31_2019_Amendare L211siL249.pdf. Accessed on 7.01.2021.

Petrişor Al.-I., Susa A. A., Petrişor L. E. (2020), Counting for sustainability: the risks of creating a market for the environment. Present Environment and Sustainable Development, 14(1), 167-184. DOI: 10.15551/pesd2020141013.

Petrişor L. E., Petrişor Al.-I. (2020), Environmental perception of young urban planners after an ecology course: the surprise of a total disagreement. Present Environment and Sustainable Development, 14(1), 37-49. DOI: $10.15551 /$ pesd2020141003.

Poli D. (2015), Sustainable food, spatial planning and agro urban public space in the bioregional city. In: Cinà G., Dansero E. (eds.), Localizing Urban Food Strategies. Farming Cities and Performing Rurality. 7th International Aesop Sustainable Food Planning Conference Proceedings. Torino, Politecnico di Torino, 83-97.

Primăria Comunei Ciugud [Ciugud Mayor's Office] (2020), Aprozarul virtual [Virtual Vegetables Shop]. URL: https://www.primariaciugud.ro/aprozarul-virtual. Accessed on 24.10.2020.
Sărăescu M. (2019), Video! Mioveniul dă din nou clasă Piteștiului. Sistem smart city integrat în premieră în Argeș cu o companie gigant din China [Video! Mioveni Surclasses Pitești Again. Integrated Smart City System in Premiere in Argeş with a Giant Company from China], May 8, 2019. URL: https://www.proarges.ro/mioveni/video-mioveniul-dadin-nou-clasa-pitestiului-sistem-smart-city-integrat-inpremiera-in-arges-cu-o-companie-gigant-din-china.

Accessed on 7.01.2021.

Scott Cato M. (2013), The bioregional economy. Land, liberty and the pursuit of happiness. London, Routledge. ISBN 9780415500821.

Snyder G. (1994), Coming in to the watershed. In: Aberley D. (ed.), Future by Design. The Practice of Ecological Planning. Gabriola Island (BC)- Washington D.C., New Society Publisher, 14-26.

Stoica I.-V., Tulla A. F., Zamfir D., Petrişor Al.-I. (2020), Exploring the urban strength of small towns in Romania. Social Indicators Research, 152(3), 843-875. DOI: $10.1007 / \mathrm{s} 11205-020-02465-\mathrm{x}$.

Stuiver M. (2006), Highlighting the retro side of innovation and its potential for regime change in agriculture. In: Marsden T., Murdoch J. (eds.), Between the Local and the Global. Bingley, Emerald, 147-173.

Szalók M., Bende Cs., Kozina J. (eds.) (2019), Plan de guvernare pentru agricultura urbană participativă în vederea combaterii excluziunii sociale în Regiunea Dunării [Participatory urban agriculture governance plan for fighting social exclusion in the Danube Region]. Central Transdanubian Regional Innovation Agency, Székesfehérvár. ISBN 978-615-00-4351-7. Thayer R. L. (2003), LifePlace: Bioregional Thought and Practice. Berkeley, University of California Press. ISBN 9780520236288.

Thayer R. L. (2013), The world shrinks, the world expands: information, energy and relocalization. In: Cook E. A., Lara J. J. (eds.), Remaking Metropolis: Global Challenges of the Urban Landscape. Abingdon, Routledge, 39-59.

Ziarul Piața Presei [Piața Presei Newspaper] (2019), Ecoinsula, sistem de colectare separată eficient pentru braşoveni [The Eco Island, An Efficient Waste Collection System in Braşov]. URL: https://www.piatapresei.ro/2019/12/ecoinsulasistemul-de-colectare-separata-eficient-pentrubrasoveni/. Accessed on 7.02.2021. 